\title{
Quantitation of Total Protein Content in Some Common Edible Food Sources by Lowry Protein Assay
}

\author{
Laxminandan Satpathy 1,* (D), Deeptimayi Dash ${ }^{1}{ }^{\mathbb{D}}$, Pritijyotsna Sahoo 2 (D), Taslima Nasim Anwar ${ }^{3}$ (D), \\ Siba Prasad Parida ${ }^{*}$ (D) \\ 1 Department of Zoology, School of Applied Sciences, Centurion University of Technology and Management, \\ Bhubaneswar, Odisha, 752050 India; laxminandansatpathy@gmail.com (L.S.); dashdeeptimayi98@gmail.com (D.D.); \\ paridasp@gmail.com (S.P.P.); \\ 2 Department of Biotechnology, Utkal University, Vani Vihar, Bhubaneswar, Odisha, 751004 India; \\ pritijyottsna1@gmail.com; \\ 3 Department of Zoology, Indira Gandhi National Tribal University, Amarkantak, Madhya Pradesh, 484886 India; \\ taslimacharmy@gmail.com; \\ * Correspondence: laxminandansatpathy@gmail.com (L.S.); paridasp@gmail.com (S.P.P.);
}

Scopus Author ID 57197747626

Received: 15.06.2020; Revised: 2.07.2020; Accepted: 3.07.2020; Published: 7.07.2020

Abstract: The nutrient value or quality of different proteins varies due to amino acid composition, ratios of essential amino acids, vulnerability to hydrolysis during digestion, source, and the effects of transforming. To enhance the biological activity of proteins, better gripping is needed for the various correlated parameters that influence their nutrient value. This research article attempts to contribute to this effort. It analyzes the Lowry method used for protein quantity evaluation. Recent studies on the nutrient quality of 11 common protein sources including oyster mushroom (Pleurotus ostreatus), white button mushroom (Agaricus bisporus); chicken (Gallus gallus domesticus); black Bengal goat (Capra hircus); brown shrimp (Metapenaeus monoceros); Mola carplet (Ambylpharyngodon mola), Rohu fish (Labeo rohita), Reba carp (Cirrhinus reba), slender rasbora (Rasbora daniconius), banded gourami (Trichogaster fasciata); and egg albumin are evaluated. The highest amount of protein present in brown shrimp, i.e., $85.982 \mathrm{mg} / \mathrm{mL}$. This study is intended to trigger interest in the use of new protein sources for nourishing the booming world population.

Keywords: Analytical method; amino acid; edible protein sources; Lowry protein assay; UV- visible spectrophotometer.

(C) 2020 by the authors. This article is an open-access article distributed under the terms and conditions of the Creative Commons Attribution (CC BY) license (https://creativecommons.org/licenses/by/4.0/).

\section{Introduction}

The nutritional requirement depends upon numerous factors such as age, location, occupation, and health condition of an individual [1]. With changing habits and increasing food adulteration, cardio-vascular diseases, obesity, hypertension, diabetes, and cancer are increasing [1]. Doctors and nutritionists found that the intake of certain food items may prevent disorders [1]. Protein is one of the food-stuff that can prevent disorders. Protein was derived from the Greek word proteios, which means "primaries", i.e., of first importance [2]. Proteins are complex nitrogen-containing organic molecules found in all animal and plant cells. It is the principal component of the living protoplasm [2]. It constitutes nearly one-half of the body's dry matter [2]. Many types of proteins present and they perform various functions like a catalytic activity for metabolic reaction in the form of enzymes; they help in muscle movement because actin and myosin are made up of protein molecules. Protein forms the structural 
material for plants, for example, cellulose and the structural proteins of animals are collagen and keratin [3]. A large number of proteins perform transportation activities inside the human body, i.e., hemoglobin in the blood and other protein molecules across the cell membrane. Many hormones are protein compounds, including human growth hormone (hGH), insulin, and erythropoietin. It helps in blood coagulation and immune response. Some proteins store materials like casein in milk and iron in the liver by ferritin. It also controls the regulation of gene expression [4]. A typical cell consists of about 9000 different proteins, and the entire human body contains 100,000 different proteins [4]. Proteins are made up of chains of amino acids linked by peptide bonds. Dietary proteins are hydrolyzed by proteases and peptidases to release amino acids, dipeptides, and tripeptides in the alimentary canal [5]. Amino acids provide nitrogen, sulfur, hydrogen, carbon, and oxygen, which are the essential components of an organism and cannot be replaced by any other nutrients like carbohydrates and lipids. It has enormous physiological importance. Therefore, amino acids are basic building blocks of proteins [6]. Over 300 amino acids are found in nature, out of which 20 constitute the monomer units of proteins [7]. Only L- $\alpha$-amino acids occur in protein molecules [7]. So, we need twenty amino acids in order to be healthy. Nine out of the twenty amino acids are called essential because bodies cannot make them. These nine essential amino acids must come from the dietary supplements we eat [8]. Protein malnutrition results in stunted growth, physical weakness, under-weight, wasting, anemia, vascular dysfunction, edema, and immunity impairment [5]. Malnutrition of protein causes metabolic disorders, Kwashiorkor, and Marasmus in humans, mostly in children of developing nations [9]. Dietary protein deficiency also occurs in elderly humans of developed countries, which makes them susceptible to metabolic and infectious diseases [10]. On the other hand, over intake of dietary protein from meals and supplementation leads to hepatic dysfunction [11]. Based on studies, the Recommended Dietary Allowance of protein for a healthy adult with minimal physical activity is $0.8 \mathrm{~g}$ protein per $\mathrm{kg}$ body weight per day [5]. To meet the daily needs such as elevating skeletal muscle protein and physical strength, dietary consumption of 1.0,1.3, and $1.6 \mathrm{~g}$ protein per $\mathrm{kg}$ body weight per day is recommended for individuals with minimal, moderate, and intense physical activity, respectively [5]. Long-term intake of protein at $2 \mathrm{~g}$ per kg body weight per day is safe for healthy adults, and the allowable upper limit is $3.5 \mathrm{~g}$ per kg body weight per day [5]. Prolong- high protein consumption of more than $2 \mathrm{~g}$ per $\mathrm{kg}$ body weight per day for adults may result in digestive, renal, and vascular abnormalities [5]. The quantity and quality of dietary proteins are the determinants of its nutritional values on humans. Dietary food that provides all the essential amino acids is known as high-quality proteins, and foods that do not provide all essential amino acids are called lower quality proteins [8]. Animal products such as meat, fish, poultry, and eggs are high-quality protein sources, whereas plant products like fruits and vegetables are low-quality protein sources [8]. Therefore, sufficient consumption of highquality proteins from animal products is crucial for optimal growth, reproduction, development, lactation, health, and survival of human beings. Being such an essential component of the human diet, it is important to know the protein content in foods, and thus it is crucial to have a reliable analytical method [12]. Dietary protein analysis is not necessarily a direct procedure. This is partly due to foods being comprised of a wide range of different nutrients, such as lipids, carbohydrates, and a variety of macro and micronutrients. Composition, food structure, and interactions between the different nutrients may reduce the quality of the protein leading to underestimation of the protein content [12]. The main objective 
of the study was to determine the protein content in common edible food. The chosen foods were mushroom, chicken, goat, shrimp, fishes, and egg.

Mushrooms were considered to be one of the most notable ingredients of cuisine throughout the world, particularly for their unique taste. There are more than 2,000 species of mushrooms found in nature, but only 25 are used as food, and few are commercially cultivated in the world [13-15]. Mushroom has significant medical properties, for example, hepatoprotective, detoxification, anti-diabetic, antioxidant, anti-allergic, anti-parasitic, anti-bacterial properties [13, 16-18]. Most of the vegetable proteins are extensively studied [19].

Chicken is commonly used as food in many cuisines throughout the world because of its low cost, adequately available, and reared easily. It is healthier than red meat because it contains a lower concentration of cholesterol and saturated fat [20].

Goat found throughout India. Black Bengal goat has higher prolificacy, resistance against common diseases, easily adapt to adverse environmental conditions, early maturity, high fertility rate, and tender meat with low intramuscular fat [21].

Shrimp has a short life span, high reproducibility. They spawn in deep water. Shrimp larvae feed on zooplankton and phytoplankton [22]. The concentration of total protein in the tissue of prawns, especially in the muscle increased with respect to age or size during growth, indicating that the quality of prawn muscle in terms of nutrient or protein accumulation improved from juvenile to sub-adult stages [23].

Fish contains high-quality protein with different varieties of vitamins and minerals such as vitamin $\mathrm{A}$, vitamin $\mathrm{D}$, phosphorus, magnesium, selenium, and iodine. So, it has a high nutritional value. Fish protein is easily digestible. Studies show that a small quantity of fish protein can compensate for the essential amino acids necessary for humans [24].

Eggs are low cost and consist of essential lipids, vitamins, minerals, and trace elements like zinc and calcium. It offers a moderate amount of calories, i.e., about $140 \mathrm{kcal} / 100 \mathrm{~g}$. Egg white and egg yolk are highly concentrated in proteins. On average, the concentration of proteins is $12.5 \mathrm{~g}$ per $100 \mathrm{~g}$ of a whole raw fresh egg. In comparison, egg yolk, with its vitelline membrane contains $15.9 \mathrm{~g}$ protein, and egg white contains $10.90 \mathrm{~g}$ protein per $100 \mathrm{~g}$ [25].

\section{Materials and Methods}

\subsection{Raw materials.}

The raw materials like an oyster mushroom, white button mushroom; chicken liver, chicken leg muscle, chicken breast; black Bengal goat liver, black Bengal muscle; brown shrimp; Mola carplet, Rohu fish, Reba carp, slender rasbora, banded gourami; and egg albumin were collected from a local market.

\subsection{Chemicals and reagents.}

The imperative chemicals and standard reagents used in the experiments were purchased from Sigma-Aldrich unless otherwise mentioned.

\section{3. $U V$-Visible spectrometry.}

A number of methods have been used to determine protein concentration, which is based on UV-visible spectroscopy. These methods use either the natural characteristic of proteins to scatter light in the UV-visible region of the electromagnetic spectrum, or they 
physically or chemically modify the proteins to make them absorb light in the UV-visible region. First, a curve of absorbance (Abs) versus protein concentration is prepared by using a series of protein solutions of known bovine serum albumin (BSA) concentrations, i.e., 0, 200, 400, 600, 800 and $1000 \mu \mathrm{g}$ per $\mathrm{mL}$ (Figure 1). Then the absorbance of the solution being analyzed, compared, and measured at the same wavelength of $750 \mathrm{~nm}$, and the unknown protein concentration was determined from the calibration curve.

\subsection{Lowry protein assay.}

Lowry protein assay, also known as the Lowry method, has been the most widely used method to estimate the quantity of proteins in biological samples [26]. It is a combination of the biuret reagent with the Folin-Ciocalteau phenol reagent, which interacts with the tryptophan and tyrosine residues present in protein [26]. This gives the solution a bluish color which can be read at $750 \mathrm{~nm}$ [26]. This method is more sensitive to low concentrations of proteins than the biuret and UV-visible spectroscopy method.

\subsection{Estimation of standard bovine serum albumin (BSA) solution.}

A standard curve was prepared as follows. Bovine serum albumin (BSA) standard solution was prepared using BSA powder dissolved in distilled water (DW), and it is diluted to a concentration of $100 \mathrm{mg} / 100 \mathrm{~mL}$, which is then stored at $4^{\circ} \mathrm{C}$. A series of dilutions $(0,2,4,6$, 8 , and $10 \mathrm{mg} /$ test tube) were made in duplicates (Table 1). The final volume in each of the test tubes was $2 \mathrm{~mL}$. For the protein solutions, $4 \mathrm{~mL}$ of alkaline copper sulfate reagent was added. Then the solution was mixed properly by using Tarson 3020 Spinix vortex shaker. The solution was incubated at room temperature for 10 minutes. Then $0.5 \mathrm{~mL}$ of folin phenol reagent was added to each tube and mixed properly by using Tarson 3020 Spinix vortex shaker. Then these solutions were incubated for 30 minutes at room temperature. By using blank, the spectrophotometer was set at zero, and the absorbance was taken at $750 \mathrm{~nm}$. The absorbance was plotted against protein concentration to get a standard calibration curve (Figure 1).

\subsection{Preparation of protein sample.}

Fresh samples of common edible proteins oyster mushroom (Pleurotus ostreatus), white button mushroom (Agaricus bisporus); chicken (Gallus gallus domesticus); black Bengal goat (Capra hircus); brown shrimp (Metapenaeus monoceros); Mola carplet (Ambylpharyngodon mola), Rohu fish (Labeo rohita), Reba carp (Cirrhinus reba), slender rasbora (Rasbora daniconius), banded gourami (Trichogaster fasciata); and egg albumin were collected from the market. Each sample was cut into small pieces and homogenized by using mortar and pestle. Then weigh $1 \mathrm{~g}$ of protein was taken by the help of Citizen MP300 digital weighing scale and mixed with $9 \mathrm{~mL}$ of sucrose solution. Then this homogenized mixture was transferred to the centrifuge tube for centrifugation in a table-top cooling centrifuge (REMI $\mathrm{C} 24 \mathrm{BL})$ at 4,000 rpm for 6 minutes. The supernatant was collected and stored at $4{ }^{\circ} \mathrm{C}$.

\subsection{Estimation of total proteins content by Lowry method for common edible protein samples.}

$1 \mathrm{~mL}$ of protein samples were taken in each test tube. $1 \mathrm{~mL}$ of distilled water was taken before taking the protein sample to prevent the degeneration of the sample protein. To these solutions, $4 \mathrm{~mL}$ of alkaline copper solution was added. Then the mixtures were mixed thoroughly by using Tarson 3020 Spinix vortex shaker. The solutions were incubated at room 
temperature for 10 minutes. Then $0.5 \mathrm{~mL}$ of Folin-Ciocalteau phenol was added to these solutions and mixed properly by using vortex Shaker. Then these solutions were incubated for 30 minutes at room temperature and in dark condition. Duplicates test tube were prepared for each sample. The reading of the absorbance of unknown samples was taken at $750 \mathrm{~nm}$ (Table $3)$.

\begin{tabular}{l|l|l|l|l|l|l|l|l}
$\begin{array}{c}\text { Test } \\
\text { tube } \\
\text { number }\end{array}$ & $\begin{array}{c}\text { Volume } \\
\text { of BSA } \\
(\mathrm{mL})\end{array}$ & $\begin{array}{c}\text { Concentrat } \\
\text { ion of } \\
\text { BSA } \\
(\mathrm{mg})\end{array}$ & $\begin{array}{l}\text { Volume of } \\
\text { distilled } \\
\text { water }(\mathrm{mL})\end{array}$ & $\begin{array}{c}\text { Alkaline } \\
\text { copper } \\
\text { solution } \\
(\mathrm{mL})\end{array}$ & $\begin{array}{c}\text { Incubate } \\
(\text { minute) }\end{array}$ & $\begin{array}{c}\text { Folin- } \\
\text { Ciocalteau } \\
\text { Phenol reagent } \\
(\mathrm{mL})\end{array}$ & $\begin{array}{c}\text { Incubate } \\
\text { in dark } \\
(\text { minute })\end{array}$ & $\begin{array}{c}\text { Absorbance } \\
\text { (Abs) at } \\
750 \mathrm{~nm}\end{array}$ \\
\hline 1 & 0.0 & 0 & 2.0 & 4 & 10 & 0.5 & 30 & 0 \\
\hline 2 & 0.2 & 200 & 1.8 & 4 & 10 & 0.5 & 30 & 0.034 \\
\hline 3 & 0.4 & 400 & 1.6 & 4 & 10 & 0.5 & 30 & 0.096 \\
\hline 4 & 0.6 & 600 & 1.4 & 4 & 10 & 0.5 & 30 & 0.131 \\
\hline 5 & 0.8 & 800 & 1.2 & 4 & 10 & 0.5 & 30 & 0.178 \\
\hline 6 & 1.0 & 1000 & 1 & 4 & 10 & 0.5 & 30 & 0.224
\end{tabular}

Table 1. Absorbance of different bovine serum albumin (BSA) concentration.

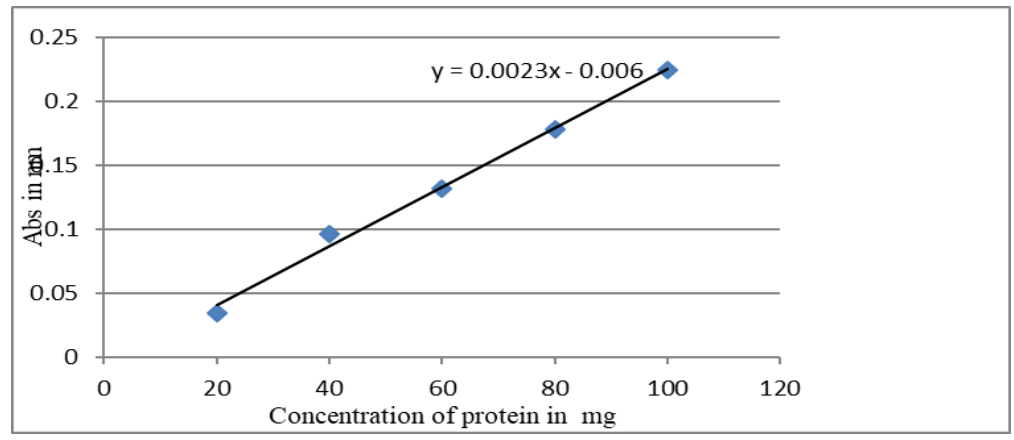

Figure 1. Bovine serum albumin standard curve (absorbance was plotted against protein concentration) using the Lowry method.

\section{Results and Discussion}

\subsection{Calculation.}

As BSA is taken as a standard solution, $100 \mathrm{mg}$ of protein (BSA) is added in $100 \mathrm{~mL}$ of distilled water that is $1 \mathrm{mg}$ in $1 \mathrm{~mL}$ or $1000 \mu \mathrm{g}$ in $1 \mathrm{~mL}$ of sample.

Hence $1 \mathrm{~mL}$ contains $1000 \mu \mathrm{g}$ or $1 \mathrm{mg}$ protein.

For $1 \mathrm{~mL}$ of BSA sample absorbance $=0.224$

At absorbance 0.224 , concentration of $\mathrm{BSA}=1000 \mu \mathrm{g}$ or $1 \mathrm{mg}$

At absorbance 1, concentration of protein $=1 / 0.224 \mathrm{mg}$

At absorbance $\mathrm{X}$ concentration protein $=1 / 0.224 \times \mathrm{X} \mathrm{mg}$

At absorbance ' $\mathrm{X}$ ' concentration of sample protein $=1 \mathrm{~mL}=1 / 0.224 \times \mathrm{X} \times 1 / 1$

But $1 \mathrm{~g}$ sample was homogenized by using $9 \mathrm{~mL}$ of sucrose so that the dilution factor will be 10.

So at absorbance $\mathrm{X}$ concentration of sample protein of $1 \mathrm{~mL}=1 / 0.224 \times \mathrm{X} \times 10$

Table 2. Analysis of different edible samples of protein by Lowry method.

\begin{tabular}{l|l|l|l}
$\begin{array}{c}\text { Serial } \\
\text { number }\end{array}$ & \multicolumn{1}{|c|}{ Sample } & Absorbance (Abs) at 750nm & Amount of protein (mg) \\
\hline 1 & Oyster mushroom & 1.011 & 45.133 \\
\hline 2 & White button mushroom & 1.209 & 53.973 \\
\hline 3 & Chicken liver & 1.762 & 78.660 \\
\hline 4 & Chicken leg muscle & 1.806 & 80.625
\end{tabular}




\begin{tabular}{l|l|l|l}
$\begin{array}{c}\text { Serial } \\
\text { number }\end{array}$ & \multicolumn{1}{|c|}{ Sample } & Absorbance (Abs) at 750nm & Amount of protein (mg) \\
\hline 5 & Chicken breast & 1.920 & 85.714 \\
\hline 6 & Black Bengal goat liver & 1.832 & 81.785 \\
\hline 7 & Black Bengal goat muscle & 1.226 & 54.732 \\
\hline 8 & Brown shrimp muscle & 1.926 & 85.982 \\
\hline 9 & Mola carplet fish muscle & 1.852 & 82.678 \\
\hline 10 & Rohu fish muscle & 1.403 & 62.633 \\
\hline 11 & Reba carp fish muscle & 1.581 & 70.580 \\
\hline 12 & Slender rasbora fish muscle & 1.641 & 73.258 \\
\hline 13 & Banded gourami fish muscle & 1.548 & 69.107 \\
\hline 14 & Egg albumin & 1.703 & 76.026
\end{tabular}

Table 3. Absorbance of different edible samples of protein using UV- visible spectrophotometer.

\begin{tabular}{|c|c|c|c|c|c|c|c|}
\hline $\begin{array}{c}\text { Serial } \\
\text { number }\end{array}$ & $\begin{array}{l}\text { Test tube } \\
\text { number }\end{array}$ & $\begin{array}{c}\text { Sample in } \\
\text { mL }\end{array}$ & $\begin{array}{c}\text { Distilled } \\
\text { water in } \\
\text { mL }\end{array}$ & $\begin{array}{l}\text { Alkaline } \\
\text { copper } \\
\text { solution in } \\
\text { mL }\end{array}$ & $\begin{array}{l}\text { Folin- } \\
\text { Ciocalteau } \\
\text { phenol } \\
\text { reagent in } \\
\text { mL }\end{array}$ & $\begin{array}{c}\text { Absorbanc } \\
\text { e (Abs) at } \\
750 \mathrm{~nm}\end{array}$ & Mean \\
\hline 1 & $\begin{array}{l}\text { Blank 1 } \\
\text { Blank 1, }\end{array}$ & $\begin{array}{l}0 \\
0\end{array}$ & $\begin{array}{l}1 \\
1 \\
\end{array}$ & $\begin{array}{l}4 \\
4 \\
\end{array}$ & $\begin{array}{l}0.5 \\
0.5 \\
\end{array}$ & $\begin{array}{l}0.000 \\
0.000 \\
\end{array}$ & 0 \\
\hline 2 & $\begin{array}{l}\text { Oyster } \\
\text { mushroom } \\
2 \\
\text { Oyster } \\
\text { mushroom } \\
2 \text {, }\end{array}$ & 1 & 1 & 4 & $\begin{array}{l}0.5 \\
0.5\end{array}$ & $\begin{array}{l}1.019 \\
1.003\end{array}$ & 1.011 \\
\hline 3 & $\begin{array}{l}\text { White } \\
\text { button } \\
\text { mushroom } \\
3 \\
\text { White } \\
\text { button } \\
\text { mushroom } \\
\text { 3, }\end{array}$ & 1 & 1 & 4 & 0.5 & $\begin{array}{l}1.235 \\
1.183\end{array}$ & 1.209 \\
\hline 4 & $\begin{array}{l}\text { Chicken } \\
\text { liver } 4 \\
\text { Chicken } \\
\text { liver 4' }\end{array}$ & $\begin{array}{l}1 \\
1\end{array}$ & $\begin{array}{l}1 \\
1\end{array}$ & $\begin{array}{l}4 \\
4\end{array}$ & $\begin{array}{l}0.5 \\
0.5\end{array}$ & $\begin{array}{l}1.818 \\
1.707\end{array}$ & 1.762 \\
\hline 5 & $\begin{array}{l}\text { Chicken leg } \\
\text { muscle 5 } \\
\text { Chicken leg } \\
\text { muscle 5, }\end{array}$ & $\begin{array}{l}1 \\
1\end{array}$ & $\begin{array}{l}1 \\
1\end{array}$ & $\begin{array}{l}4 \\
4\end{array}$ & $\begin{array}{l}0.5 \\
0.5\end{array}$ & $\begin{array}{l}1.804 \\
1.808\end{array}$ & 1.806 \\
\hline 6 & $\begin{array}{l}\text { Chicken } \\
\text { breast 6 } \\
\text { Chicken } \\
\text { breast 6' }\end{array}$ & $\begin{array}{l}1 \\
1\end{array}$ & $\begin{array}{l}1 \\
1\end{array}$ & $\begin{array}{l}4 \\
4\end{array}$ & $\begin{array}{l}0.5 \\
0.5\end{array}$ & $\begin{array}{l}1.926 \\
1.914\end{array}$ & 1.920 \\
\hline 7 & $\begin{array}{l}\text { Black } \\
\text { Bengal goat } \\
\text { liver } 7 \\
\text { Black } \\
\text { Bengal goat } \\
\text { liver 7, } \\
\end{array}$ & 1 & 1 & 4 & $\begin{array}{l}0.5 \\
0.5\end{array}$ & $\begin{array}{l}1.801 \\
1.769\end{array}$ & 1.832 \\
\hline 8 & $\begin{array}{l}\text { Black } \\
\text { Bengal goat } \\
\text { muscle 8 } \\
\text { Black } \\
\text { Bengal goat } \\
\text { muscle 8, } \\
\end{array}$ & 1 & 1 & 4 & 0.5 & $\begin{array}{l}1.218 \\
1.235\end{array}$ & 1.226 \\
\hline 9 & $\begin{array}{l}\text { Brown } \\
\text { shrimp } \\
\text { muscle } 9 \\
\text { Brown } \\
\text { shrimp } \\
\text { muscle 9' } \\
\end{array}$ & 1 & 1 & 4 & 0.5 & $\begin{array}{l}1.974 \\
1.879\end{array}$ & 1.926 \\
\hline 10 & $\begin{array}{l}\text { Mola } \\
\text { carplet fish } \\
\text { muscle } 10\end{array}$ & 1 & 1 & 4 & 0.5 & 1.892 & 1.852 \\
\hline
\end{tabular}




\begin{tabular}{|c|c|c|c|c|c|c|c|}
\hline $\begin{array}{c}\text { Serial } \\
\text { number }\end{array}$ & $\begin{array}{l}\text { Test tube } \\
\text { number }\end{array}$ & $\begin{array}{c}\text { Sample in } \\
\mathrm{mL}\end{array}$ & $\begin{array}{c}\text { Distilled } \\
\text { water in } \\
\mathrm{mL}\end{array}$ & $\begin{array}{l}\text { Alkaline } \\
\text { copper } \\
\text { solution in } \\
\text { mL }\end{array}$ & $\begin{array}{l}\text { Folin- } \\
\text { Ciocalteau } \\
\text { phenol } \\
\text { reagent in } \\
\text { mL }\end{array}$ & $\begin{array}{c}\text { Absorbanc } \\
\text { e (Abs) at } \\
750 \mathrm{~nm}\end{array}$ & Mean \\
\hline & $\begin{array}{l}\text { Mola } \\
\text { carplet fish } \\
\text { muscle } 10\end{array}$ & 1 & 1 & 4 & 0.5 & 1.812 & \\
\hline 11 & $\begin{array}{l}\text { Rohu fish } \\
\text { muscle } 11 \\
\text { Rohu fish } \\
\text { muscle } 11\end{array}$ & $\begin{array}{l}1 \\
1\end{array}$ & $\begin{array}{l}1 \\
1\end{array}$ & $\begin{array}{l}4 \\
4\end{array}$ & $\begin{array}{l}0.5 \\
0.5\end{array}$ & $\begin{array}{l}1.422 \\
1.385\end{array}$ & 1.403 \\
\hline 12 & $\begin{array}{l}\text { Reba carp } \\
\text { fish muscle } \\
12 \\
\text { Reba carp } \\
\text { fish muscle } \\
12 \text {, }\end{array}$ & 1 & 1 & 4 & $\begin{array}{l}0.5 \\
0.5\end{array}$ & $\begin{array}{l}1.638 \\
1.525\end{array}$ & 1.581 \\
\hline 13 & $\begin{array}{l}\text { Slender } \\
\text { rasbora fish } \\
\text { muscle } 13 \\
\text { Slender } \\
\text { rasbora fish } \\
\text { muscle 13' }\end{array}$ & 1 & 1 & 4 & $\begin{array}{l}0.5 \\
0.5\end{array}$ & $\begin{array}{l}1.681 \\
1.602\end{array}$ & 1.641 \\
\hline 14 & $\begin{array}{l}\text { Banded } \\
\text { gourami } \\
\text { fish muscle } \\
14 \\
\text { Banded } \\
\text { gourami } \\
\text { fish muscle } \\
14 \text { ' }\end{array}$ & 1 & 1 & 4 & 0.5 & 1.522 & 1.548 \\
\hline 16 & $\begin{array}{l}\text { Egg } \\
\text { albumin } 16 \\
\text { Egg } \\
\text { albumin 16, }\end{array}$ & $\begin{array}{l}1 \\
1\end{array}$ & $\begin{array}{l}1 \\
1\end{array}$ & $\begin{array}{l}4 \\
4\end{array}$ & $\begin{array}{l}0.5 \\
0.5\end{array}$ & $\begin{array}{l}1.754 \\
1.703\end{array}$ & 1.729 \\
\hline
\end{tabular}

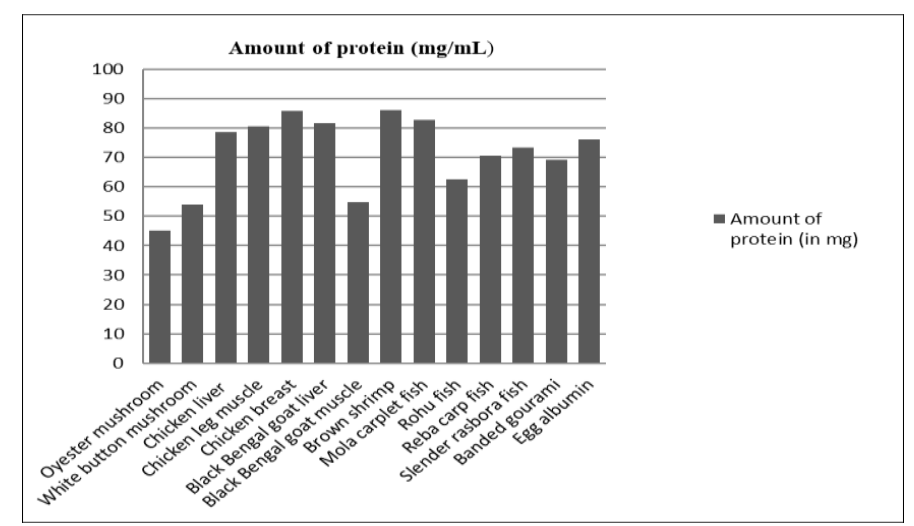

Figure 2. Different protein concentrations present in common edible sources.

The protein concentration of oyster mushroom is $45.133 \mathrm{mg}$, white button mushroom is $53.973 \mathrm{mg}$; chicken liver is $78.660 \mathrm{mg}$, chicken leg muscle is $80.625 \mathrm{mg}$, chicken breast is $85.714 \mathrm{mg}$; black Bengal goat liver is $81.785 \mathrm{mg}$, black Bengal goat muscle is $54.732 \mathrm{mg}$; brown shrimp muscle is $85.982 \mathrm{mg}$; Mola carplet fish muscle is $82.678 \mathrm{mg}$, Rohu fish muscle is $62.633 \mathrm{mg}$, Reba carp fish muscle is $70.580 \mathrm{mg}$, slender rasbora fish muscle is $73.258 \mathrm{mg}$, banded gourami fish muscle is $69.107 \mathrm{mg}$, and eggs albumin is $76.026 \mathrm{mg}$ (Table 2). Protein concentration is found to be highest in brown shrimp muscle and lowest in oyster mushroom (Figure 2). 


\section{Conclusions}

From the result of this experiment, it was found that brown shrimp had more protein content than chicken, fishes, goat, and egg albumin. Further detailed and comprehensive analysis is suggested to be undertaken on these samples taking protein concentration into consideration because these edible foods are easily available in the local market, which would be very helpful to fight against protein deficiency, malnutrition, food for the fast-growing world population.

\section{Funding}

This research received no external funding.

\section{Acknowledgments}

This research has no acknowledgment.

\section{Conflicts of Interest}

The authors declare no conflict of interest.

\section{References}

1. Duhan, N.; Barak, S.; Mudgil, D. Bioactive Lipids: Chemistry \& Health Benefits. Biointerface Research in Applied Chemistry 2020, 10, 6676-6687.

2. Rosenfeld, L. Origins of Clinical Chemistry. 1st ed.; Academic Press: New York, U.S.A., 1982; pp. 1-17, https://doi.org/10.1016/B978-0-12-597580-3.50009-4.

3. Shaikhiev, I.G.; Kraysman, N.V.; Sverguzova, S.V.; Spesivtseva, S.E.; Yarothckina, A.N. Fish Scales as a Biosorbent of Pollutants from Wastewaters and Natural Waters: a Literature Review. Biointerface Research in Applied Chemistry 2020, 10, 6893-6905.

4. Bettelheim, F.A.; Brown, W.H.; Campbell, M.K.; Farrell, S.O.; Torres, O.J. Introduction to General, Organic, and Biochemistry. 10th ed.; Brooks/Cole Cengage Learning: California, U.S.A., 2013; pp. 592632.

5. $\mathrm{Wu}, \mathrm{G}$. Dietary protein intake and human health. Food \& function 2016, 7, 1251-1265, https://doi.org/10.1039/C5FO01530H.

6. Cooper, G.M. The Cell: A Molecular Approach. 2nd ed.; Sinauer Associates: Sunderland (MA), U.S.A., 2000; pp. 52-57,

7. Rodwell, V.W.; Bender, D.; Botham, K.M.; Kennelly, P.J.; Weil, P.A. Harper's Illustrated Biochemistry. 31st ed.; Mc Graw-Hill: New York, U.S.A., 2018; pp. 14-20.

8. Kraft, D. The A-Z Guide to Food as Medicine. 2nd ed.; CRC Press: Boca Raton, U.S.A., 2019; pp. 105-388, https://doi.org/10.1201/9780429486289.

9. Leser, S. FAO dietary protein report. Nutrition Bulletin 2013, 38, 421-428, https://doi.org/10.1111/nbu.12063.

10. Dasgupta, M.; Sharkey, J.R.; Wu, G. Inadequate intakes of indispensable amino acids among homebound older adults. J Nutr Elder 2005, 24, 85-99, https://doi.org/10.1300/J052v24n03_07.

11. Hoffer, L.J.; Bistrian, B.R. Appropriate protein provision in critical illness: a systematic and narrative review. Am J Clin Nutr 2012, 96, 591-600, https://doi.org/10.3945/ajcn.111.032078.

12. Mæhre, H.K.; Dalheim, L.; Edvinsen, G.K.; Elvevoll, E.O.; Jensen, I.J. Protein Determination-Method Matters. Foods 2018, 7, https://doi.org/10.3390/foods7010005.

13. Kanchi, S.; Inamuddin; Khan, A. Biogenic Synthesis of Selenium Nanoparticles with Edible Mushroom Extract: Evaluation of Cytotoxicity on Prostate Cancer Cell Lines and Their Antioxidant, and Antibacterial Activity. Biointerface Research in Applied Chemistry 2020, 10, 6629-6639.

14. Chang, S.T.; Miles, P.G. Mushrooms: Cultivation, Nutritional Value, Medicinal Effect, and Environmental Impact. 2nd ed.; CRC Press: Boca Raton, U.S.A., 2004; pp. 2-46, https://doi.org/10.1201/9780203492086.

15. Ergönül, P.G.; Akata, I.; Kalyoncu, F.; Ergönül, B. Fatty acid compositions of six wild edible mushroom species. Scientif. World J 2013, 2013, 1-4, https://doi.org/10.1155/2013/163964.

16. Finimundy, T.C.; Gambato, G.R.; Fontana, R.; Camassola, M.; Salvador, M.; Moura, S.; Hess, J.; Henriques, J.A.; Dillon, A.J.; Roesch-Ely, M. Aqueous extracts of Lentinula edodes and Pleurotus sajor-caju exhibit 
high antioxidant capability and promising in vitro antitumor activity. Nutr. Res 2013, 33, 76-84, https://doi.org/10.1016/j.nutres.2012.11.005.

17. Yu, S.; Weaver, V.; Martin, K.; Cantorna, M.T. The effects of whole mushrooms during inflammation. BMC Immunol 2009, 10, 12, https://doi.org/10.1186/1471-2172-10-12.

18. Valverde, M.E.; Hernández-Pérez, T.; Paredes-López, O. Edible mushrooms: improving human health and promoting quality life. Int J Microbiol. 2015; 2015, https://doi.org/10.1155/2015/376387.

19. Martinez, K.D.; Pilosof, Ana M.R. Foaming behaviour of enzymatically modified sunflower protein in proximity to $\mathrm{pI}$. Biointerface Research in Applied Chemistry 2017, 7, 1883-1886.

20. Meat, Poultry, and Fish: Picking Healthy Proteins. Available online: https://www.heart.org/en/healthyliving/healthy-eating/eat-smart/nutrition-basics/meat-poultry-and-fish-picking-healthyproteins\#mainContent (accessed on 30 June 2020).

21. Siddiki, A.Z.; Baten, A.; Billah, M.; Alam, M.A.U.; Shawrob, K.S.M.S.; Saha, S.; Chowdhury, M.; Rahman, A.H.; Stear, M.; Miah, G.; Kumkum, M.; Islam, S.I.; Hossain, M.A.; Mollah, A.K.M.M.; Khan, M.K.I. The genome of the Black Bengal goat (Capra hircus). BMC Res Notes 2019, 12, https://doi.org/10.1186/s13104019-4400-3.

22. Better Management Practices. Available online: https://www.mpeda.gov.in/MPEDA/lv.php\# (accessed on 30 June 2020).

23. Cesar, JRdeO.; Zhao, B.; Malecha, S.; Ako, H.; Yang, J. Morphological and biochemical changes in the muscle of the marine shrimp Litopenaeus vannamei during the molt cycle. Aquaculture 2006, 261, 688-694, https://doi.org/10.1016/j.aquaculture.2006.08.003.

24. Fish is food for the brain as well as good protein. Available online: http://www.fao.org/focus/e/fisheries/nutr.htm (accessed on 30 June 2020).

25. Réhault-Godbert, S.; Guyot, N.; \& Nys, Y. The Golden Egg: Nutritional Value, Bioactivities, and Emerging Benefits for Human Health. Nutrients 2019, 11, 3, https://doi.org/10.3390/nu11030684.

26. Lowry, O.H.; Rosebrough, N.J.; Farr, A.L.; Randall, R.J. Protein measurement with the Folin phenol reagent. J Biol Chem. 1951, 193, 265-275. 